\title{
Cytotoxicity of $\sigma$-Receptor Ligands Is Associated with Major Changes of Cellular Metabolism and Complete Occupancy of the $\sigma-2$ Subpopulation
}

\author{
Anna A. Rybczynska ${ }^{1}$, Rudi A. Dierckx ${ }^{1}$, Kiichi Ishiwata ${ }^{2}$, Philip H. Elsinga ${ }^{1}$, and Aren van Waarde ${ }^{1}$ \\ ${ }^{I}$ Nuclear Medicine and Molecular Imaging, University of Groningen Medical Center, University of Groningen, Groningen, \\ The Netherlands; and ${ }^{2}$ Positron Medical Center, Tokyo Metropolitan Institute of Gerontology, Tokyo, Japan
}

Tumor cells can be selectively killed by application of $\sigma$-ligands; high concentrations $(20-100 \mu \mathrm{M})$ are often required, however, because either diffusion barriers must be passed to reach intracellular sites or the entire $\sigma$-receptor population should be occupied to induce cell death. We measured receptor occupancies associated with the cytotoxic effect and dose-dependent changes of cellular metabolism in a tumor cell line. Methods: C6 cells (rat glioma) were grown in monolayers and exposed to $(+)$-pentazocine ( $\sigma-1$ agonist), AC915 ( $\sigma-1$ antagonist), rimcazole $(\sigma-1 / \sigma-2$ antagonist), or haloperidol ( $\sigma-1 / \sigma-2$ antagonist). Occupancy of $\sigma$-receptors by the test drugs was measured by studying the competition of the test drugs with cellular binding of the ligand ${ }^{11} \mathrm{C}-\mathrm{SA} 4503$. Metabolic changes were quantified by measuring cellular uptake of ${ }^{18} \mathrm{~F}-\mathrm{FDG},{ }^{18} \mathrm{~F}-\mathrm{FLT},{ }^{11} \mathrm{C}$-choline, or ${ }^{11} \mathrm{C}$ methionine. Cytotoxicity was assessed by cellular morphology observation and cell counting after $24 \mathrm{~h}$. Results: $I_{50}$ values (drug concentrations resulting in 50\% occupancy of the available binding sites) of the test drugs for inhibition of cellular ${ }^{11} \mathrm{C}-\mathrm{SA} 4503$ binding were $6.5,7.4,0.36$, and $0.27 \mu \mathrm{M}$ for (+)-pentazocine, AC915, rimcazole, and haloperidol, respectively. EC $_{50}$ values (dose required for a $50 \%$ reduction of cell number after $24 \mathrm{~h}$ ) were $710,819,31$, and $58 \mu \mathrm{M}$, for pentazocine, AC915, rimcazole, and haloperidol, respectively. Cytotoxic doses of $\sigma$-ligands were generally associated with increased uptake of ${ }^{18} \mathrm{~F}-\mathrm{FDG}$, decreased uptake of ${ }^{18} \mathrm{~F}-\mathrm{FLT}$ and ${ }^{11} \mathrm{C}$-choline, and little change in ${ }^{11} \mathrm{C}$-methionine uptake per viable cell. Conclusion: $\mathrm{IC}_{50}$ values of the test drugs reflect their in vitro affinities to $\sigma-2$ rather than to $\sigma-1$ receptors. Because cytotoxicity occurred at concentrations 2 orders of magnitude higher than $\mathrm{IC}_{50}$ values for inhibition of cellular ${ }^{11} \mathrm{C}-\mathrm{SA} 4503$ binding, high (99\%) occupancy of $\sigma-2$ receptors is associated with loss of cell viability. ${ }^{18} \mathrm{~F}-\mathrm{FLT},{ }^{11} \mathrm{C}$-choline, and ${ }^{18} \mathrm{~F}-\mathrm{FDG}$ responded most strongly to drug treatment and showed changes corresponding to the cytotoxicity of the test compounds.

Key Words: PET; $\sigma$-receptor occupancy; cellular proliferation; glioma cells; ${ }^{18} \mathrm{~F}-\mathrm{FLT} ;{ }^{18} \mathrm{~F}-\mathrm{FDG} ;{ }^{11} \mathrm{C}$-choline; ${ }^{11} \mathrm{C}$-methionine

J Nucl Med 2008; 49:2049-2056

DOI: $10.2967 /$ jnumed.108.053876

\footnotetext{
Received Apr. 25, 2008; revision accepted Aug. 15, 2008.

For correspondence or reprints contact: Aren van Waarde, Nuclear Medicine and Molecular Imaging, University of Groningen Medical Center, Hanzeplein 1, 9700 RB Groningen, The Netherlands.

E-mail: a.van.waarde@ngmb.umcg.nl

COPYRIGHT ( 2008 by the Society of Nuclear Medicine, Inc.
}

$\mathbf{S}_{\mathrm{i}}$

igma receptors are unique proteins integrated in plasma and endoplasmatic reticulum membranes of tissue derived from immune, endocrine, and reproductive organs; kidney; liver; and brain ( 1 ). $\sigma$-receptors were initially considered as a subtype of the opioid receptor but were later shown to be unlike any other known neurotransmitter or hormone binding site (2). After $30 \mathrm{y}$ of extensive research, understanding of the molecular cascade triggered by these transmembrane proteins is still rudimentary (3). The 2 confirmed $\sigma$-receptor subtypes, $25-\mathrm{kD} \sigma-1$ and $21.5-\mathrm{kD} \sigma-2$ (4), are strongly overexpressed in rapidly proliferating cells, for example, in cancer cells from animals and humans, as compared with healthy tissue (5-7). Although the sequence and partial structure of the $\sigma-1$ receptor are already established $(8,9)$, the existence of the $\sigma-2$ receptor has been proven only pharmacologically (10).

Many natural substances from plant extracts and newly synthesized compounds were tested for $\sigma$-receptor binding, resulting in the availability of a broad range of $\sigma$-receptor ligands today (11). Interestingly, some of these compounds were shown to be effective antineoplastic agents $(12,13)$. Later, in vitro $(14-16)$ and in vivo $(17,18)$ studies confirmed that $\sigma$-ligands such as haloperidol and rimcazole inhibit growth of both cultured cancer cells and in vivo tumors, whereas they do not affect proliferation or survival of the noncancer tissue (18). These studies highlighted the potency of $\sigma$-ligands to kill cancer cells with minimal side effects. In most cell lines, including in C6 rat glioma, cell death was observed only after administration of high concentrations (20-100 $\mu \mathrm{M})$ of a $\sigma-1$ receptor antagonist or a $\sigma-2$ receptor agonist $(12,13)$. The reason for the requirement of high concentrations is unknown. Possibly biomembranes limit drug access to intracellular sites, or a high fraction of the $\sigma$-receptor population should be occupied to kill tumor cells.

If a suitable radioligand for $\sigma$-receptors is available, dose-dependent occupancy of the receptor population by an exogenous ligand can be assessed by performing a competition assay in intact cells. Measured occupancy values can 
be subsequently compared with the dose-dependent effects of test drugs on cellular morphology and growth. The $\sigma-1$ agonist SA4503, labeled with the positron emitter ${ }^{11} \mathrm{C}$, is available for this purpose (19). We used C6 cells as an in vitro model for the measurement of both $\sigma$-receptor occupancy and cytotoxic effects. This rat glioma cell line has been used extensively in previous research because it expresses high densities of both $\sigma-1$ and $\sigma-2$ receptors (6). Rimcazole $(\sigma-1 / \sigma-2$ receptor antagonist), haloperidol $(\sigma-1 / \sigma-2$ receptor antagonist), $(+)$-pentazocine $(\sigma-1$ receptor agonist), and AC915 ( $\sigma-1$ receptor antagonist) were chosen as our model compounds because these drugs are commercially available and are potent $\sigma$-receptor ligands (20-23). Several metabolic PET tracers, such as ${ }^{18} \mathrm{~F}-\mathrm{FDG}$, $3^{\prime}$-deoxy-3'-fluorothymidine $\left({ }^{18} \mathrm{~F}-\mathrm{FLT}\right),{ }^{11} \mathrm{C}$-choline, and ${ }^{11} \mathrm{C}$-methionine, are routinely produced in our laboratory. These radiopharmaceuticals track changes in cellular metabolism and may show altered uptake kinetics after antitumor therapy (24). Thus, we could assess the dosedependent effects of $\sigma$-ligands on cellular biochemistry.

The present study aimed to answer the following questions: Which concentrations of $\sigma$-ligands should be administered to occupy a substantial fraction of the intracellular receptor population and kill C6 cells? At which level of receptor occupancy does cell death occur? Can PET tracers detect any changes of cellular metabolism after $\sigma$-ligand binding? Which PET tracer is the most sensitive indicator of reduced cellular viability?

\section{MATERIALS AND METHODS}

\section{Culture Medium and Drugs}

Dulbecco's minimum essential medium (DMEM), fetal calf serum (FCS), and trypsin were products of Invitrogen. AC915, haloperidol, $(+)$-pentazocine, rimcazole, and trypan blue $(0.4 \%$ solution in phosphate-buffered saline) were purchased from Sigma. AC915 was dissolved in water with slight heating, and haloperidol and rimcazole were dissolved in ethanol. Stock solutions of (+)-pentazocine were made in $0.1 \mathrm{~N}$ hydrochloric acid.

\section{Radiopharmaceuticals}

${ }^{11} \mathrm{C}$-methionine, ${ }^{11} \mathrm{C}$-choline, ${ }^{18} \mathrm{~F}$-FLT, and ${ }^{18} \mathrm{~F}$-FDG were prepared by standard procedures reported in the literature $(25) .{ }^{11} \mathrm{C}$ SA4503 was prepared by reaction of ${ }^{11} \mathrm{C}$-methyl iodide with the appropriate 4-O-methyl precursor (26). Specific radioactivity at the end of synthesis was greater than $22 \mathrm{TBq} / \mathrm{mmol}$. All radiochemical purities were greater than $95 \%$.

\section{Cell Culture}

C6 rat glioma cells obtained from the American Type Culture Collection were grown as monolayers in DMEM (high glucose) supplemented with $7.5 \%$ FCS in a humidified atmosphere of 5\% $\mathrm{CO}_{2} / 95 \%$ air at $37^{\circ} \mathrm{C}$. Before each experiment, the cells were seeded in 12-well plates (Costar). An equal number of cells was dispensed in each well and was supplied with $1.1 \mathrm{~mL}$ of DMEM (high glucose) supplemented with 7.5\% FCS.

\section{Binding Studies}

Binding studies were performed $48 \mathrm{~h}$ after seeding cells in 12 -well plates, when confluency reached $80 \%-90 \%$. Various concentrations of an unlabeled competitor (AC915, haloperidol, (+)-pentazocine, or rimcazole; range, $10^{-8}$ to $10^{-3} \mathrm{M}$, in triplicate) were dispensed to the culture medium in the wells. After $2 \mathrm{~min}, 4 \mathrm{MBq}$ of ${ }^{11} \mathrm{C}$-SA4503 in less than $30 \mu \mathrm{L}$ of saline (containing 30\% ethanol) were added to each well. After about 45 min of incubation, the medium was quickly removed, and the monolayer was washed 3 times with phosphate-buffered saline. Cells were then treated with $0.2 \mathrm{~mL}$ of trypsin. When the monolayer had detached from the bottom of the well, $1 \mathrm{~mL}$ of DMEM (high glucose) supplemented with $7.5 \%$ FCS was applied to stop the proteolytic action. Cell aggregates were resolved by repeated (at least 10-fold) pipetting of the trypsin/DMEM mixture. Radioactivity in the cell suspension $(1.2 \mathrm{~mL})$ was assessed using a $\gamma$-counter (Compugamma $1282 \mathrm{CS}$; LKB-Wallac). A sample of the suspension was mixed with trypan blue solution $(1: 1 \mathrm{v} / \mathrm{v})$ and used for cell counting. Cell numbers were manually determined, using a phase-contrast microscope (Olympus), a Bürker brightline chamber (depth, $0.1 \mathrm{~mm} ; 0.0025 \mathrm{~mm}^{2}$ squares), and a handtally counter.

Uptake of radioactivity normalized to the number of viable cells was plotted against the logarithm of the dose of the competing drug (in $[\mathrm{M}]$ ). A 3-parameter curve (single-site competition model) was fitted to these data, using the following equation:

$$
\mathrm{Y}=\text { bottom }+(\text { top }- \text { bottom }) /\left(1+10^{\left(\mathrm{X}-\operatorname{logIC}_{50}\right)}\right),
$$

where $\mathrm{IC}_{50}$ is drug concentration resulting in 50\% occupancy of the available binding sites. GraphPad Prism (GraphPad Software) was used for curve fitting and graphical presentation of data. Less than $6 \%$ (in most wells $<<5 \%$ ) of the administered tracer dose was bound to the cells under these conditions.

\section{Treatment with $\sigma$-Ligands and Scoring of Morphologic Effects}

$\sigma$-Ligands were administered $24 \mathrm{~h}$ after seeding cells in 12 -well plates when confluency had reached $40 \%-45 \%$. Final concentrations in culture medium were $1,3,10,30$, and 100 (in some cases also 300) times the $\mathrm{IC}_{50}$ value of the test drug for inhibition of ${ }^{11} \mathrm{C}$-SA4503 binding to cellular $\sigma$-receptors (determined as described above).

After 20-24 h of incubation with $\sigma$-ligands, the cells were monitored by phase-contrast microscopy. The effect of each compound and concentration was scored relative to a control receiving only solvent vehicle. Scoring was performed as described previously (12). Experiments were performed in quadruplicate and repeated at least twice. Decreases of cell number after drug treatment were quantified by harvesting and resuspending cells in medium containing FCS, followed by manual counting as described above.

\section{Uptake Studies}

Cellular uptake of metabolic PET tracers was determined after $24 \mathrm{~h}$ of treatment with either vehicle or a $\sigma$-ligand. Experiments were performed in quadruplicate and repeated at least twice. At time zero, a PET tracer (4 MBq of ${ }^{11} \mathrm{C}$-methionine or ${ }^{11} \mathrm{C}$-choline or $2 \mathrm{MBq}$ of ${ }^{18} \mathrm{~F}-\mathrm{FDG}$ or ${ }^{18} \mathrm{~F}$-FLT in $<20 \mu \mathrm{L}$ of saline) was added to each well. After $45 \mathrm{~min}$ of incubation, cells were washed, and cellular radioactivity was assessed as described above. Less than $1 \%\left({ }^{11} \mathrm{C}\right.$-methionine), $2 \%\left({ }^{18} \mathrm{~F}-\mathrm{FDG}\right)$, or $4 \%\left({ }^{11} \mathrm{C}\right.$-choline and 
${ }^{18} \mathrm{~F}-\mathrm{FLT}$ ) of the administered tracer dose was taken up by the cells under these conditions.

\section{Statistics}

Differences between groups were examined using 1-way ANOVA. A $P$ value of less than 0.05 was considered statistically significant.

\section{RESULTS}

\section{Receptor Occupancy}

Curves describing competition between the test drugs and the radioligand ${ }^{11} \mathrm{C}-\mathrm{SA} 4503$ for cellular $\sigma$-receptors are presented in Figure 1. The data were best fitted by a 1-site competition model. $\mathrm{IC}_{50}$ values were either in the submicromolar range (rimcazole, $0.36 \mu \mathrm{M}$; haloperidol, 0.27 $\mu \mathrm{M})$ or in the micromolar range $((+)$-pentazocine, $6.5 \mu \mathrm{M}$; AC915, $7.4 \mu \mathrm{M})$.

\section{Subtype Involvement}

Table 1 lists literature values for the affinities $\left(\mathrm{K}_{\mathrm{d}}\right)$ of the test compounds to $\sigma-1$ and $\sigma-2$ receptors, determined by in

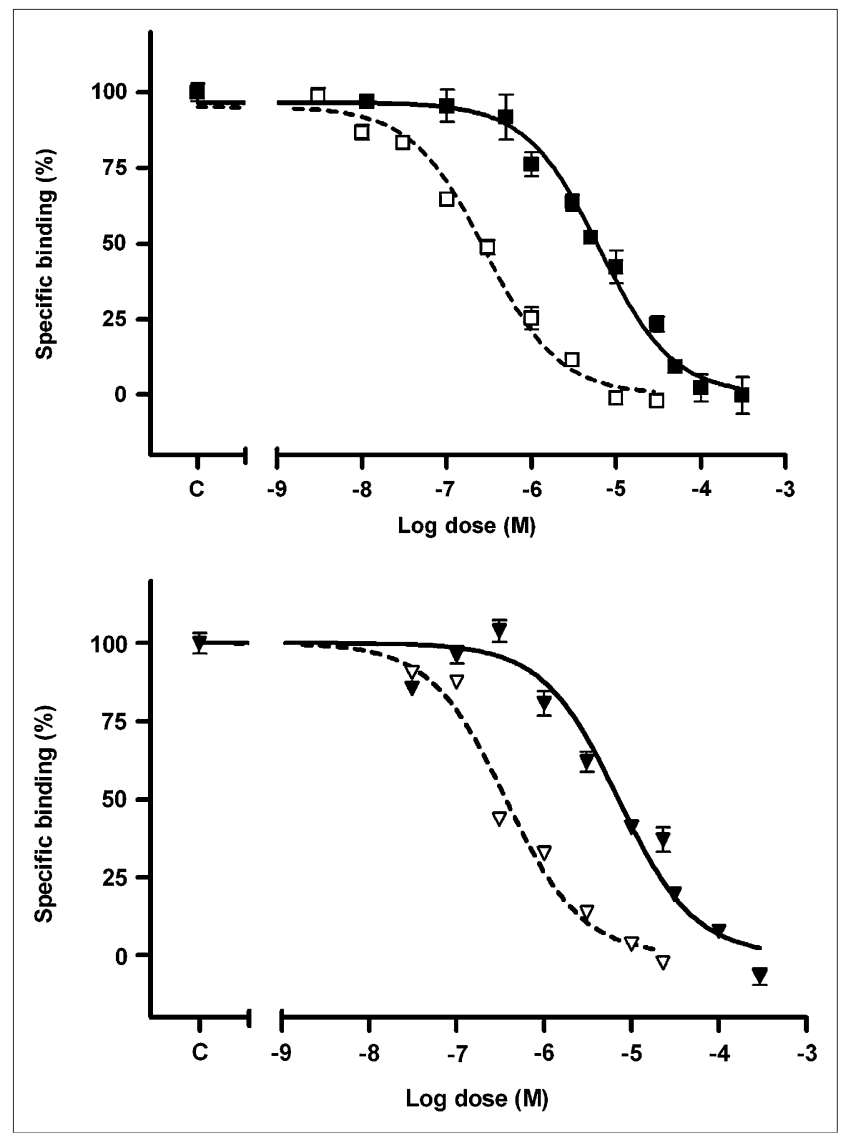

FIGURE 1. Dose-dependent increase of cellular ${ }^{11} \mathrm{C}-\mathrm{SA} 4503$ binding by (+)-pentazocine ( $\square)$, haloperidol $(\square)$, AC915 ( $\nabla)$, and rimcazole $(\nabla)$. Error bars indicate SEM. Specific binding was calculated by subtracting nonspecific binding (i.e., residual binding of radioligand in presence of highest dose of competing drug) from total binding; it amounted to $70 \%-80 \%$ of total radioactivity uptake by cells. vitro binding assays using membrane fragments isolated from rodent tissues. We observed much higher (60- to 1,500 -fold) $\mathrm{IC}_{50}$ values in intact cells than known $\mathrm{K}_{\mathrm{d}}$ values at $\sigma-1$ receptors, particularly in the case of AC915, $(+)$-pentazocine, and haloperidol. However, $\mathrm{IC}_{50}$ values of all test compounds corresponded closely to their $\mathrm{K}_{\mathrm{d}}$ values at $\sigma-2$ receptors. Here, only minor $(<3$-fold $)$ differences were observed. Therefore, $\mathrm{IC}_{50}$ values for inhibition of ${ }^{11} \mathrm{C}-\mathrm{SA} 4503$ binding to intact cells corresponded to the $\sigma-2 \mathrm{~K}_{\mathrm{d}}$ rather than to the $\sigma-1 \mathrm{~K}_{\mathrm{d}}$ of the test compounds.

\section{Cytotoxicity}

When the $\sigma$-antagonists rimcazole, haloperidol, or AC915 were applied to $\mathrm{C} 6$ cells in culture, a dose-dependent growth inhibition was observed after $24 \mathrm{~h}$ (Fig. 2). Low doses of the test drugs did not affect cellular growth. Above a certain threshold concentration (rimcazole, $20 \mu \mathrm{M}$; haloperidol, $25 \mu \mathrm{M}$; and AC915, $220 \mu \mathrm{M}$ ), a reduction in cell number became apparent. $\mathrm{EC}_{50}$ values of the test compounds (effective concentrations resulting in $50 \%$ cell loss) were somewhat higher than the threshold for cytotoxicity (rimcazole, $31 \mu \mathrm{M}$; haloperidol, $58 \mu \mathrm{M}$; and AC915, $819 \mu \mathrm{M})$. Virtually complete cell death was observed after $24 \mathrm{~h}$ of treatment with either $100 \mu \mathrm{M}$ rimcazole or $150 \mu \mathrm{M}$ haloperidol (Fig. 2). Even $200 \mu \mathrm{M} \sigma-1$ agonist (+)-pentazocine did not yet affect cell division or viability. Here, the $\mathrm{EC}_{50}$ value for growth inhibition was $710 \mu \mathrm{M}$.

\section{Receptor Occupancy at Cytotoxic Dose}

By comparing $\mathrm{EC}_{50}$ values of the test compounds with their $\mathrm{IC}_{50}$ values for inhibition of ${ }^{11} \mathrm{C}-\mathrm{SA} 4503$ binding in intact cells, $\sigma$-receptor occupancies at cytotoxic doses of the test drugs could be estimated, using the curves presented in Figure 1 or the formula for a single-site competition model (see "Materials and Methods"). Because $\mathrm{EC}_{50}$ values were about 2 orders of magnitude higher than the corresponding $\mathrm{IC}_{50}$ values of the test drugs, cell death appeared to be associated with virtually complete (i.e., $99 \%$ ) occupancy of the $\sigma$-receptor population (Table 2).

\section{Changes of Cellular Metabolism}

The metabolic PET tracers that we used responded differently to treatment of C6 cells with $\sigma$-receptor ligands. Cytotoxic doses of (+)-pentazocine, haloperidol, and rimcazole were generally associated with increases of the uptake of ${ }^{18} \mathrm{~F}$-FDG, decreases of the uptake of ${ }^{18} \mathrm{~F}$-FLT and ${ }^{11} \mathrm{C}$-choline, and little change of ${ }^{11} \mathrm{C}$-methionine uptake per viable cell (Figs. 3-6).

Significant increases of ${ }^{18}$ F-FDG uptake were observed only when a certain threshold concentration was exceeded. The threshold dose for haloperidol and rimcazole was 10 $\mu \mathrm{M}$ but in the case of (+)-pentazocine was $30 \mu \mathrm{M}$ (Fig. 3). Maximal increases of ${ }^{18}$ F-FDG uptake $(+111 \%,+150 \%$, and $+166 \%$ for haloperidol, rimcazole, and $(+)$-pentazocine, respectively; all statistically significant) occurred at doses of $100 \mu \mathrm{M}$ for haloperidol, $112 \mu \mathrm{M}$ for rimcazole, and 660 $\mu \mathrm{M}$ for (+)-pentazocine. Higher doses of test drug could 
TABLE 1

Binding of Test Compounds to $\sigma$-Receptor Subtypes

\begin{tabular}{|c|c|c|c|c|c|}
\hline \multirow[b]{2}{*}{ Test drug } & \multicolumn{2}{|c|}{$\mathrm{K}_{\mathrm{d}}(\mathrm{nM})$} & \multirow{2}{*}{$\begin{array}{l}\mathrm{IC}_{50} \text { for inhibition of } \\
{ }^{11} \mathrm{C}-\mathrm{SA} 4503 \\
\text { binding in C6 cells (nM) }\end{array}$} & \multicolumn{2}{|c|}{$\mathrm{IC}_{50} / \mathrm{K}_{\mathrm{d}}$} \\
\hline & $\sigma_{1}$-receptor & $\sigma_{2}$-receptor & & $\sigma_{1}$-receptor & $\sigma_{2}$-receptor \\
\hline AC915 & 4.9 (rat liver) (22) & $>10,000$ (rat liver) (22) & 7,358 & 1,502 & 0.7 \\
\hline (+)-Pentazocine & $\begin{array}{l}7.0 \text { (rat brain) (21); } \\
5.5 \text { (rat brain) }(23)\end{array}$ & $\begin{array}{l}2,470 \text { (rat liver) (23); } \\
1,923 \text { (rat liver) (38) }\end{array}$ & 6,495 & $928-1,181$ & $2.6-3.4$ \\
\hline Haloperidol & $\begin{array}{l}4.7 \text { (rat brain) (39); } \\
2.6 \text { (rat brain) }(23)\end{array}$ & 167 (rat liver) (23) & 274 & $58-105$ & 1.6 \\
\hline Rimcazole & 690 (guinea pig brain) (20) & 180 (guinea pig brain) (20) & 356 & $0.5-0.8$ & 2.0 \\
\hline
\end{tabular}

not be examined, because these resulted in a complete loss of cells after $24 \mathrm{~h}$. In contrast to the previously mentioned $\sigma$-ligands, AC915 in doses of up to $776 \mu \mathrm{M}$ did not increase cellular ${ }^{18} \mathrm{~F}$-FDG uptake. A slight but statistically significant decline $(-21 \%)$ of ${ }^{18} \mathrm{~F}-\mathrm{FDG}$ uptake was observed after incubation of cells with $220 \mu \mathrm{M}$ AC915 (Fig. 3).

Treatment of C6 cells with rimcazole, (+)-pentazocine, and haloperidol resulted in a dose-dependent depression of

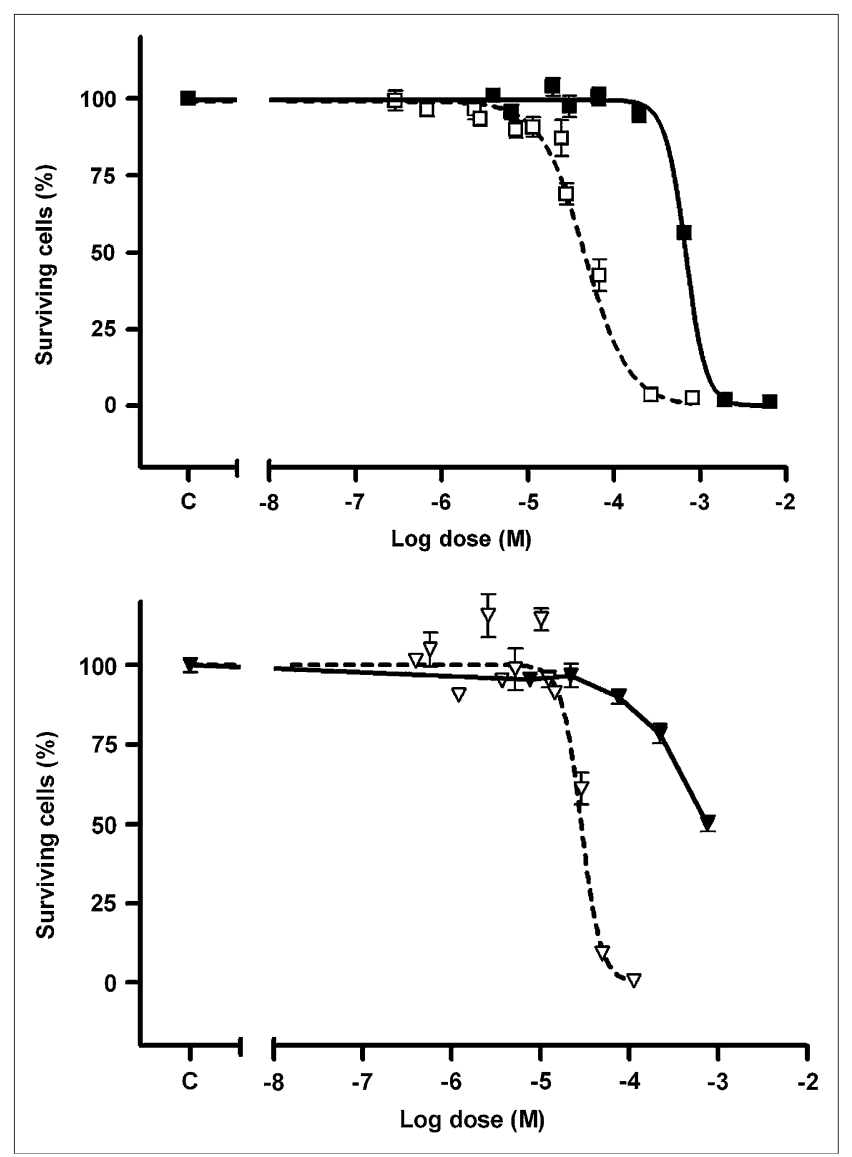

FIGURE 2. Dose-dependent cell loss after $24 \mathrm{~h}$ of incubation with (+)-pentazocine $(\boldsymbol{\nabla})$, haloperidol $(\square)$, AC915 ( $\boldsymbol{\nabla})$, and rimcazole $(\nabla)$. Note that $x$-axis scales of Figures 1 and 2 are different. Error bars indicate SEM.
${ }^{18}$ F-FLT uptake when drug concentrations exceeded threshold values of 20, 50, and $80 \mu \mathrm{M}$, respectively (Fig. 4). Strong and statistically significant depression of ${ }^{18} \mathrm{~F}$-FLT uptake was observed after a 24-h incubation of the cells with 50 (rimcazole), 100 (haloperidol), or $645 \mu \mathrm{M}((+)-$ pentazocine), to $6 \%, 17 \%$, and $26 \%$ of the control, respectively. In contrast to the previously mentioned $\sigma$-ligands, AC915 did not depress cellular ${ }^{18} \mathrm{~F}$-FLT uptake but caused a biphasic increase with a maximum occurring at a drug dose of $74 \mu \mathrm{M}$ (Fig. 4).

Cellular uptake of ${ }^{11} \mathrm{C}$-choline was depressed by all drug treatments (Fig. 5). A decline occurred when the ligand concentration of (+)-pentazocine and AC915 exceeded $70 \mu \mathrm{M}(20 \mu \mathrm{M}$ for haloperidol and $15 \mu \mathrm{M}$ for rimcazole). At concentrations of $650((+)$-pentazocine), 711 (AC915), or $45 \mu \mathrm{M}$ (rimcazole), ${ }^{11} \mathrm{C}$-choline uptake was reduced more than $80 \%$, whereas a concentration of $60 \mu \mathrm{M}$ for haloperidol resulted in a 55\% decline (Fig. 5).

No statistically significant changes of ${ }^{11} \mathrm{C}$-methionine uptake occurred after $24 \mathrm{~h}$ of treatment of C6 cells with (+)-pentazocine, haloperidol, or AC915 (Fig. 6). In contrast, rimcazole at concentrations greater than $10 \mu \mathrm{M}$ depressed uptake of the amino acid up to $40 \%$ (Fig. 6).

\section{DISCUSSION}

\section{Competition Assays}

${ }^{11} \mathrm{C}-\mathrm{SA} 4503$ has been reported to bind preferentially to $\sigma-1$ receptors $\left(\mathrm{IC}_{50}, 17.4 \mathrm{nM}\right.$ at the $\sigma-1$ and $1,784 \mathrm{nM}$ at the $\sigma-2$ subtype (27); $\mathrm{IC}_{50}, 4.7 \mathrm{nM}$ at $\sigma-1$ and $63.1 \mathrm{nM}$ at $\sigma-2$ receptors in a later study (28)). Therefore, we expected that the potent $\sigma-1$ selective ligands (+)-pentazocine and AC915 would compete more efficiently (i.e., at lower $\mathrm{IC}_{50}$ values) with cellular binding of ${ }^{11} \mathrm{C}$-SA4503 than would the non-subtype-selective antagonists rimcazole and haloperidol, which bind less potently to $\sigma-1$ receptors. In reality, however, rimcazole and haloperidol inhibited ${ }^{11} \mathrm{C}$ SA4503 binding more potently ( $\mathrm{IC}_{50}$ values, 0.36 and 0.27 $\mu \mathrm{M}$, respectively) than did (+)-pentazocine and AC915 ( $\mathrm{IC}_{50}$ values, 6.5 and $7.4 \mu \mathrm{M}$, respectively; Fig. 1). The $\mathrm{IC}_{50}$ values corresponded closely to the $\sigma-2 \mathrm{~K}_{\mathrm{d}}$ but not to the $\sigma-1 \mathrm{~K}_{\mathrm{d}}$ of the test compounds (Table 1).

This outcome of our competition assays can be understood when the applied mass of ${ }^{11} \mathrm{C}-\mathrm{SA} 4503$ is considered. 
TABLE 2

Receptor Occupancy at Cytotoxic Dose

\begin{tabular}{lcccc}
\hline \multicolumn{1}{c}{ Test drug } & $\begin{array}{c}\mathrm{IC}_{50} \text { for inhibition of } \\
{ }^{11} \mathrm{C}-\mathrm{SA} 4503 \text { binding } \\
\text { in C6 cells }(\mu \mathrm{M})\end{array}$ & $\begin{array}{c}\mathrm{EC}_{50} \text { for cell killing } \\
\text { (within } 24 \mathrm{~h} ; \mu \mathrm{M})\end{array}$ & $\begin{array}{c}\mathrm{EC}_{50} / \mathrm{IC}_{50} \\
\text { occupancy }(\%)\end{array}$ \\
\hline AC915 & 7.4 & 819 & 110 & 99.1 \\
(+)-Pentazocine & 6.5 & 710 & 109 & 99.1 \\
Haloperidol & 0.27 & 58 & 215 & 99.5 \\
Rimcazole & 0.36 & 31 & 86 & 98.9 \\
\hline
\end{tabular}

To have acceptable count statistics even at high doses of a competing drug after $60 \mathrm{~min}$ of incubation, it was necessary to add $4 \mathrm{MBq}$ of ${ }^{11} \mathrm{C}-\mathrm{SA} 4503$. At a specific radioactivity of $22 \mathrm{TBq} / \mathrm{mmol}$, this corresponds to a ligand mass of $0.2 \mathrm{nmol}$ and a ligand concentration of $200 \mathrm{nM}$ in each well. The receptor $K_{d}$ reported by Matsuno et al. (27) predict that at this radioligand concentration, saturation of $\sigma-1$ receptors will occur and specific binding will be observed mainly at the $\sigma-2$ subtype.

Thus, the methods described in this article investigated the relationship between cytotoxicity and $\sigma-2$ receptor

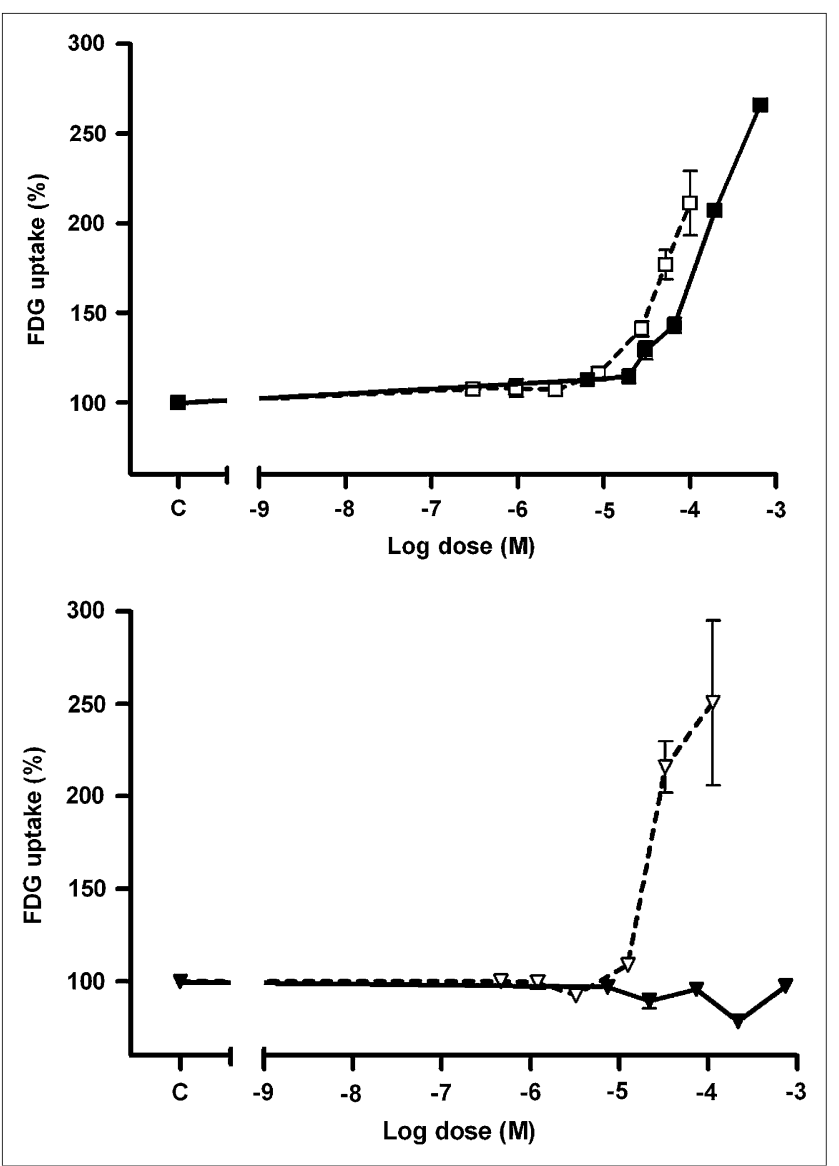

FIGURE 3. Dose-dependent increase of cellular ${ }^{18} \mathrm{~F}-\mathrm{FDG}$ uptake by $(+)$-pentazocine $(\square)$, haloperidol $(\square)$, AC915 ( $\nabla)$, and rimcazole $(\nabla)$. occupancy, using the relatively low affinity of ${ }^{11} \mathrm{C}-\mathrm{SA} 4503$ for $\sigma-2$ receptors. During in vivo scans with ${ }^{11} \mathrm{C}-\mathrm{SA} 4503$ in humans, ligand concentrations in the $10^{-8}$ or $10^{-7} \mathrm{M}$ range will never be reached. Human SA4503-PET scans will, therefore, reflect the regional distribution of $\sigma-1$ rather than $\sigma$-receptors.

\section{Cytotoxic Effects}

According to the literature, relatively high doses of $\sigma$-antagonists $(20-100 \mu \mathrm{M}$ for rimcazole or haloperidol $(12,13))$ are required for the killing of glioma cells. Our

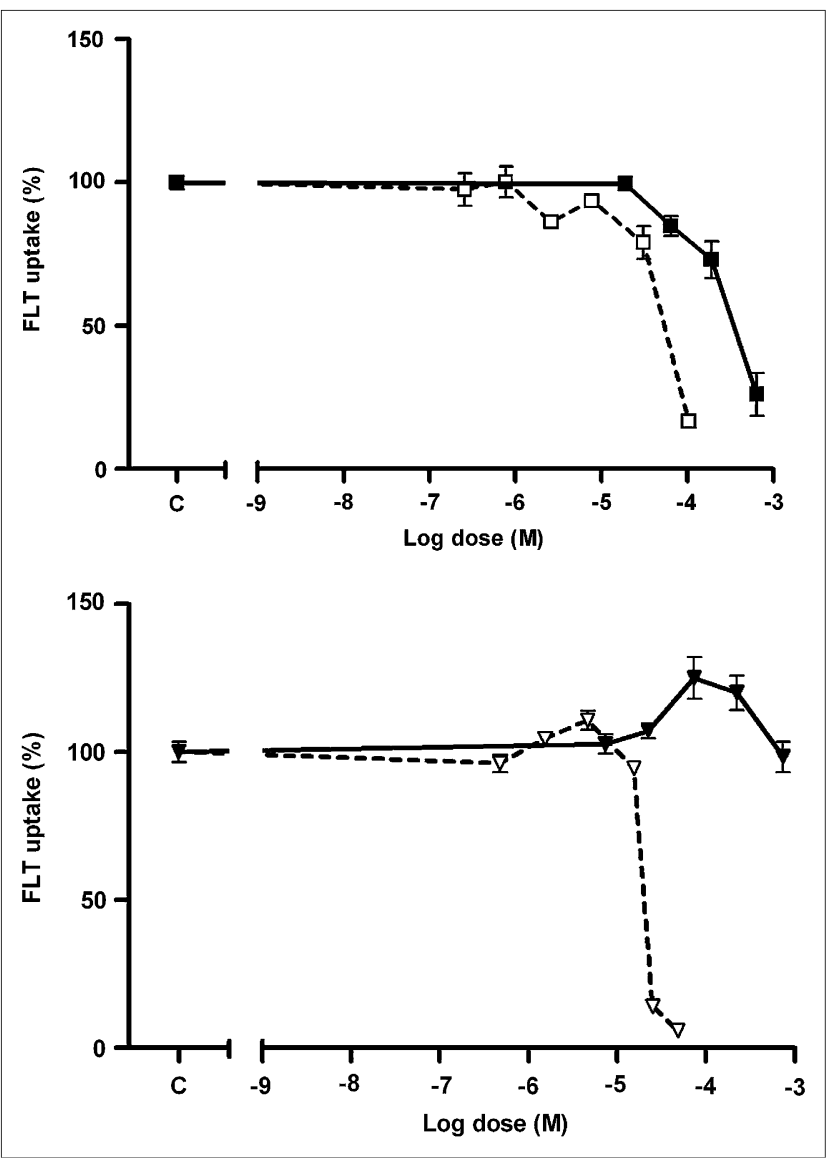

FIGURE 4. Dose-dependent inhibition of cellular ${ }^{18} \mathrm{~F}-\mathrm{FLT}$ uptake by $(+)$-pentazocine $(\boldsymbol{\nabla})$, haloperidol $(\square), \operatorname{AC915}(\boldsymbol{\nabla})$, and rimcazole $(\nabla)$. 


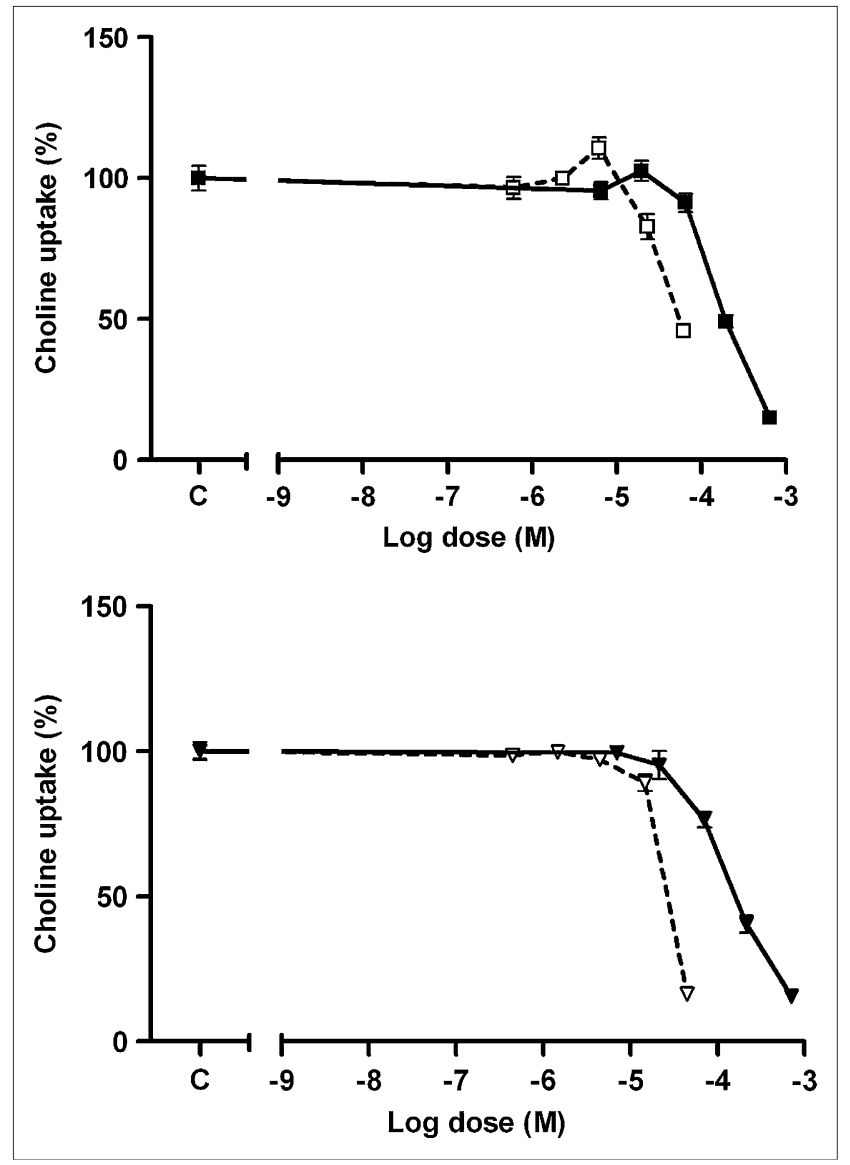

FIGURE 5. Dose-dependent inhibition of cellular ${ }^{11} \mathrm{C}$-choline uptake by (+)-pentazocine ( $\nabla)$, haloperidol $(\square)$, AC915 ( $\nabla)$, and rimcazole $(\nabla)$.

data confirm these reports $\left(\mathrm{EC}_{50}, 31 \mu \mathrm{M}\right.$ for rimcazole and $58 \mu \mathrm{M}$ for haloperidol; Fig. 2). Even higher doses of (+)pentazocine and AC915 were necessary to induce cell death (EC 50 values, 710 and $819 \mu \mathrm{M}$, respectively; Fig. 2). Such high doses are not required because diffusion barriers limit drug access to intracellular sites, for half-maximal occupancy of the $\sigma$-receptor population is reached already at concentrations 100-fold lower than the $\mathrm{EC}_{50}$ for cell killing (Table 2). Because we observed a decrease in cellular viability only at drug concentrations 2 orders of magnitude higher than the corresponding $\mathrm{IC}_{50}$ values for inhibition of ${ }^{11} \mathrm{C}$-SA4503 binding, our data indicate that cell death is associated with virtually complete $(>98 \%)$ occupancy of the $\sigma$-receptor population. Because ${ }^{11} \mathrm{C}$-SA4503 binding occurred mainly at $\sigma-2$ receptors under the conditions of our assay, the data also suggest that cell death is induced via the $\sigma-2$ rather than via the $\sigma-1$ subtype if the observed cytotoxic effects are really mediated through $\sigma$-receptors.

The curves describing cell loss after $24 \mathrm{~h}$ of treatment with rimcazole and $(+)$-pentazocine have a steep slope, indicating rapid cell killing when the drug dose exceeds a sharp threshold concentration (Fig. 2). In contrast, cell death induced by haloperidol and AC915 occurs more grad-
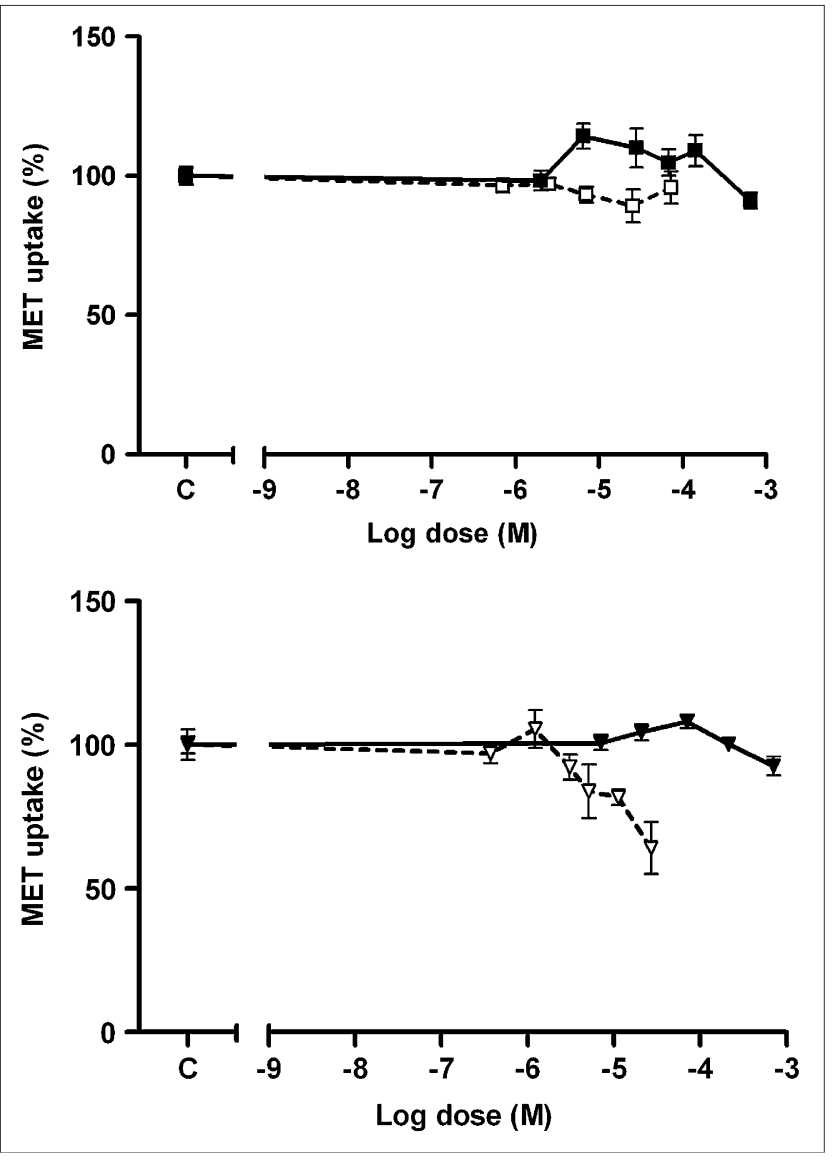

FIGURE 6. Dose-dependent inhibition of cellular ${ }^{11} \mathrm{C}$-methionine uptake by $(+)$-pentazocine $(\boldsymbol{\square})$, haloperidol $(\square)$, AC915 ( $\nabla)$, and rimcazole $(\nabla)$. MET $=$ methionine.

ually (Fig. 2). These different curve shapes may signify that haloperidol and AC915 are partial agonists at $\sigma-2$ receptors, whereas rimcazole and $(+)$-pentazocine are full agonists. It is also possible that rimcazole and $(+)$-pentazocine induce cell death via an additional mechanism, which occurs in parallel and independently of occupancy of the $\sigma-2$ receptor population. $\sigma-2$ receptor-mediated cell death is suggested by the fact that losses of cell viability always occur at concentrations 2 orders of magnitude higher than the $\mathrm{IC}_{50}$ of the 4 test compounds for inhibition of ${ }^{11} \mathrm{C}$-SA4503 binding to cellular $\sigma-2$ receptors (Table 2). An additional mechanism of cell death is suggested by the different shapes of the cellloss curves (Fig. 2) and by a cellular morphology that is different after treatment of the cells with different $\sigma$-ligands (data not shown).

On the basis of these data, rimcazole appears to be the most interesting compound for further study as an anticancer drug.

\section{Metabolic Changes}

In our in vitro model, we observed a large increase of ${ }^{18} \mathrm{~F}$-FDG uptake after $24 \mathrm{~h}$ of incubation with $\sigma$-receptor ligands (Fig. 3). A similar increase of ${ }^{18} \mathrm{~F}-\mathrm{FDG}$ uptake has 
been observed after some forms of chemo- and radiotherapy in which the increase of uptake preceded cell death $(29,30)$. This increase may be a "metabolic flare" due to increased energy consumption as a consequence of DNA and membrane repair (29). Glucose transporters (glucose transporter 1 and sodium-dependent glucose transporter 1) are known to be overexpressed after various cellular stresses, including hypoxia and heat shock (31). Rimcazole and $(+)$-pentazocine interfered strongly with cellular ${ }^{18} \mathrm{~F}-\mathrm{FDG}$ uptake, whereas haloperidol and AC915 had smaller effects on glucose metabolism (Fig. 3).

${ }^{18} \mathrm{~F}-\mathrm{FLT}$ traces the salvage pathway of DNA synthesis. The retention of this nucleoside is a measure of thymidine kinase 1 activity within the cells $(32,33)$. After treatment of C6 cells with $\sigma$-receptor ligands, we observed striking decreases of ${ }^{18}$ F-FLT uptake. (+)-Pentazocine, rimcazole, and haloperidol induced more than a $70 \%$ decline of cellular ${ }^{18} \mathrm{~F}$-FLT uptake at a dose 100 times greater than the $\mathrm{IC}_{50}$ for inhibition of cellular ${ }^{11} \mathrm{C}-\mathrm{SA} 4503$ binding (Fig. 4). However, AC915 caused a less marked inhibition of ${ }^{18} \mathrm{~F}$-FLT uptake, which is consistent with a smaller reduction of cellular proliferation (Fig. 4). The rank order of drug effects on ${ }^{18} \mathrm{~F}$-FLT uptake was the same as for ${ }^{18} \mathrm{~F}$-FDG. In the range of 3-30 times $\mathrm{IC}_{50}$ for inhibition of cellular ${ }^{11} \mathrm{C}-\mathrm{SA} 4503$ binding, AC915 induced a small increase of ${ }^{18}$ F-FLT uptake, which may reflect activation of repair processes within the cells.

We tested ${ }^{11} \mathrm{C}$-choline uptake after treatment of C6 cells with $\sigma$-receptor ligands because total choline levels and phosphatidylcholine synthesis are known to be elevated in cancers of different origin, as compared with healthy tissue, and are related to cellular proliferation. We observed the expected strong decrease of ${ }^{11} \mathrm{C}$-choline uptake when cells were treated with $\sigma$-ligands (Fig. 5). Above the threshold rimcazole concentration, the uptake of ${ }^{11} \mathrm{C}$-choline was reduced rapidly, whereas (+)-pentazocine, AC915, and haloperidol resulted in slower but progressive inhibition of phospholipid metabolism. These results are consistent with the fact that ${ }^{11} \mathrm{C}$-choline uptake by cancer cells is related to the activity of the enzyme choline kinase (34), which is generally directly proportional to the proliferative status of the cell.

In contrast to ${ }^{18} \mathrm{~F}$-FLT and ${ }^{11} \mathrm{C}$-choline, ${ }^{11} \mathrm{C}$-methionine did not behave as a proliferation marker, and ${ }^{11} \mathrm{C}$-methionine uptake per viable cell showed hardly any change (Fig. 6). Thus, ${ }^{11} \mathrm{C}$-methionine appeared to trace cell number rather than cellular viability after $\sigma$-ligand treatment. The methyl group of methionine, which contains the ${ }^{11} \mathrm{C}$ label, is implicated in many metabolic processes such as protein synthesis, transmethylation, and polyamine synthesis. Therefore, ${ }^{11} \mathrm{C}$-methionine has a complex metabolism, and uptake of ${ }^{11} \mathrm{C}$-methionine by tumor cells may be a reflection of several processes, which are affected differently by anticancer treatment, some being increased and others showing a decrease (35). The lack of change in ${ }^{11} \mathrm{C}$-methionine uptake may also indicate unaltered transport of this amino acid through the cell membrane and slow transmethylation processes (31).

Our data indicate that ${ }^{18} \mathrm{~F}$-FLT and ${ }^{11} \mathrm{C}$-choline are the tracers of choice for evaluation of the effects of $\sigma$-ligands on cellular proliferation. ${ }^{18} \mathrm{~F}-\mathrm{FDG}$ may also provide useful information, but ${ }^{11} \mathrm{C}$-methionine uptake is a reflection of the cell number rather than the proliferation state.

Growth reduction of glioma cells and changes of cellular metabolism were observed only at ligand concentrations more than 30-fold higher than those required for $50 \%$ occupancy of the $\sigma-2$ receptor population. Strong decreases of the number of viable cells occurred at drug concentrations greater than or equal to 100 -fold higher than the $\mathrm{IC}_{50}$ for inhibition of ${ }^{11} \mathrm{C}-\mathrm{SA} 4503$ binding. Thus, cell death was associated with virtually complete (99\%) occupancy of the intracellular $\sigma$-2 receptor pool.

Although high levels of receptor occupancy and drug doses in the $10^{-5} \mathrm{M}$ range are required for rapid cell killing, $\sigma$-ligands appear to have potential as cancer therapeutics for the following reasons. First, preliminary studies, both from our own laboratory and from other institutions (18), have demonstrated that cell death is limited to tumor cells and occurs only at much higher concentrations in healthy normal cells. Adverse effects could be further diminished by local application or selective drug targeting. Second, significant inhibition of in vivo tumor growth has been observed in a variety of tumor models in response to $\sigma$-ligands given systemically $(17,18)$. Third, because $\sigma-2$ ligands trigger cell death both by caspasedependent and caspase-independent mechanisms, such compounds may be suitable for treatment of a wide variety of tumors, including caspase-deficient tumor types (36). Last, subtoxic doses of $\sigma$-ligands can be applied in combination therapy and can potentiate the antitumor effects of "classic" cytostatic agents $(36,37)$. Because of the therapeutic potential of $\sigma$-ligands, radiopharmaceuticals for $\sigma$-receptors may be used not only as diagnostic imaging agents but also as tools to assess $\sigma$-receptor occupancy during experimental tumor therapy.

\section{CONCLUSION}

In the present study, treatment of tumor cells with cytotoxic doses of $\sigma$-ligands resulted in strong increases of the uptake of ${ }^{18} \mathrm{~F}-\mathrm{FDG}$ and decreases of ${ }^{18} \mathrm{~F}$-FLT and ${ }^{11} \mathrm{C}$-choline uptake per viable cell. Cell-specific uptake of ${ }^{11} \mathrm{C}$-methionine was largely unaltered under these conditions. ${ }^{18} \mathrm{~F}$-FLT, ${ }^{11} \mathrm{C}$-choline, and ${ }^{18} \mathrm{~F}$-FDG responded strongly to drug treatment and were suitable tools in the evaluation of the cytotoxicity of the test compounds. These PET tracers may, therefore, be used in future in vivo studies.

\section{REFERENCES}

1. Su TP. Sigma receptors: putative links between nervous, endocrine and immune systems. Eur J Biochem. 1991;200:633-642. 
2. Quirion R, Chicheportiche R, Contreras PC, et al. Classification and nomenclature of phencyclidine and sigma binding receptor sites. Trends Neurosci. 1987;10:444-446.

3. Hayashi T, Su TP. An update on the development of drugs for neuropsychiatric disorders: focusing on the $\sigma_{1}$ receptor ligand. Expert Opin Ther Targets. 2008; 12:45-58.

4. Hellewell SB, Bruce A, Feinstein G, Orringer J, Williams W, Bowen WD. Rat liver and kidney contain high densities of sigma 1 and sigma 2 receptors: characterization by ligand binding and photoaffinity labeling. Eur J Pharmacol. 1994;268:9-18.

5. Aydar E, Onganer P, Perrett R, Djamgoz MB, Palmer CP. The expression and functional characterization of sigma $\sigma 1$ receptors in breast cancer cell lines. Cancer Lett. 2006;242:245-257.

6. Vilner BJ, John CS, Bowen WD. Sigma-1 and sigma-2 receptors are expressed in a wide variety of human and rodent tumor cell lines. Cancer Res. 1995;55:408-413.

7. Thomas GE, Szucs M, Mamone JY, et al. Sigma and opioid receptors in human brain tumors. Life Sci. 1990;46:1279-1286.

8. Kekuda R, Prasad PD, Fei YJ, Leibach FH, Ganapathy V. Cloning and functional expression of the human type 1 sigma receptor (hSigmaR1). Biochem Biophys Res Commun. 1996;229:553-558.

9. Mei JF, Pasternak GW. Molecular cloning and pharmacological characterization of the rat sigma ${ }_{1}$ receptor. Biochem Pharmacol. 2001;62:349-355.

10. Guitart X, Codony X, Monroy X. Sigma receptors: biology and therapeutic potential. Psychopharmacology (Berl). 2004;174:301-319.

11. Newman AH, Coop A. Medicinal chemistry: new chemical classes and subtypeselective ligands. In: Matsumoto RR, Bowen WD, Su TP, eds. Sigma Receptors: Chemistry, Cell Biology and Clinical Implications. Berlin, Germany: Springer Verlag; 2007:25-44.

12. Vilner BJ, de Costa BR, Bowen WD. Cytotoxic effects of sigma ligands: sigma receptor-mediated alterations in cellular morphology and viability. J Neurosci. 1995;15:117-134.

13. Brent PJ, Pang GT. Sigma binding site ligands inhibit cell proliferation in mammary and colon carcinoma cell lines and melanoma cells in culture. Eur J Pharmacol. 1995;278:151-160.

14. Brent PJ, Pang G, Little G, Dosen PJ, Van Helden DF. The sigma receptor ligand, reduced haloperidol, induces apoptosis and increases intracellular-free calcium levels $[\mathrm{Ca} 2+] \mathrm{i}$ in colon and mammary adenocarcinoma cells. Biochem Biophys Res Commun. 1996;219:219-226.

15. Colabufo NA, Berardi F, Contino M et al. Antiproliferative and cytotoxic effects of some $\sigma_{2}$ agonists and $\sigma_{1}$ antagonists in tumour cell lines. Naunyn Schmiedebergs Arch Pharmacol. 2004;370:106-113.

16. Nordenberg J, Perlmutter I, Lavie G, et al. Anti-proliferative activity of haloperidol in B16 mouse and human SK-MEL-28 melanoma cell lines. Int J Oncol. 2005;27:1097-1103.

17. Moody TW, Leyton J, John C. Sigma ligands inhibit the growth of small cell lung cancer cells. Life Sci. 2000;66:1979-1986.

18. Spruce BA, Campbell LA, McTavish N, et al. Small molecule antagonists of the sigma-1 receptor cause selective release of the death program in tumor and selfreliant cells and inhibit tumor growth in vitro and in vivo. Cancer Res. 2004; 64:4875-4886.

19. Kawamura K, Ishiwata $\mathrm{K}$, Tajima $\mathrm{H}$, et al. In vivo evaluation of $\left[{ }^{11} \mathrm{C}\right] \mathrm{SA} 4503$ as a PET ligand for mapping CNS sigma ${ }_{1}$ receptors. Nucl Med Biol. 2000;27: 255-261.

20. Ferris RM, Harfenist M, McKenzie GM, Cooper B, Soroko FE, Maxwell RA. BW 234U, (cis-9-(3,5-dimethyl-1-piperazinyl)propyl]carbazole dihydrochloride): a novel antipsychotic agent. J Pharm Pharmacol. 1982;34:388-390.
21. Cagnotto A, Bastone A, Mennini T. $\left[{ }^{3} \mathrm{H}\right](+)$-pentazocine binding to rat brain sigma 1 receptors. Eur J Pharmacol. 1994;266:131-138.

22. Maeda DY, Williams W, Bowen WD, Coop A. A sigma-1 receptor selective analogue of BD1008: a potential substitute for $(+)$-opioids in sigma receptor binding assays. Bioorg Med Chem Lett. 2000;10:17-18.

23. Ishiwata K, Kawamura K, Yajima K, QingGeLeTu, Mori H, Shiba K. Evaluation of $(+)$-p- $\left[{ }^{11} \mathrm{C}\right]$ methylvesamicol for mapping sigmal receptors: a comparison with $\left[{ }^{11} \mathrm{C}\right] \mathrm{SA} 4503$. Nucl Med Biol. 2006;33:543-548.

24. Van Waarde A, Been LB, Ishiwata K, Dierckx RA, Elsinga PH. Early response of sigma-receptor ligands and metabolic PET tracers to 3 forms of chemotherapy: an in vitro study in glioma cells. $J$ Nucl Med. 2006;47:1538-1545.

25. Van Waarde A, Jager PL, Ishiwata K, Dierckx RA, Elsinga PH. Comparison of sigma-ligands and metabolic PET tracers for differentiating tumor from inflammation. J Nucl Med. 2006;47:150-154.

26. Kawamura K, Elsinga PH, Kobayashi T, et al. Synthesis and evaluation of ${ }^{11} \mathrm{C}$ - and ${ }^{18}$ F-labeled 1-[2-(4-alkoxy-3-methoxyphenyl)ethyl]-4-(3-phenylpropyl)piperazines as sigma receptor ligands for positron emission tomography studies. Nucl Med Biol. 2003;30:273-284.

27. Matsuno K, Nakazawa M, Okamoto K, Kawashima Y, Mita S. Binding properties of SA4503, a novel and selective sigma 1 receptor agonist. Eur J Pharmacol. 1996;306:271-279.

28. Lever JR, Gustafson JL, Xu R, Allmon RL, Lever SZ. $\sigma_{1}$ and $\sigma_{2}$ receptor binding affinity and selectivity of SA4503 and fluoroethyl SA4503. Synapse. 2006;59: 350-358.

29. Slosman DO, Pugin J. Lack of correlation between tritiated deoxyglucose, thallium-201 and technetium-99m-MIBI cell incorporation under various cell stresses. J Nucl Med. 1994;35:120-126.

30. Furuta M, Hasegawa M, Hayakawa K, et al. Rapid rise in FDG uptake in an irradiated human tumour xenograft. Eur J Nucl Med. 1997;24:435-438.

31. Clavo AC, Wahl RL. Effects of hypoxia on the uptake of tritiated thymidine, L-leucine, L-methionine and FDG in cultured cancer cells. J Nucl Med. 1996;37: 502-506.

32. Rasey JS, Grierson JR, Wiens LW, Kolb PD, Schwartz JL. Validation of FLT uptake as a measure of thymidine kinase-1 activity in A549 carcinoma cells. J Nucl Med. 2002;43:1210-1217.

33. Barthel H, Perumal M, Latigo J, et al. The uptake of $3^{\prime}$-deoxy-3'$\left[{ }^{18} \mathrm{~F}\right]$ fluorothymidine into L5178Y tumours in vivo is dependent on thymidine kinase 1 protein levels. Eur J Nucl Med Mol Imaging. 2005;32:257-263.

34. Yoshimoto M, Waki A, Obata A, Furukawa T, Yonekura Y, Fujibayashi Y. Radiolabeled choline as a proliferation marker: comparison with radiolabeled acetate. Nucl Med Biol. 2004;31:859-865.

35. Vaalburg W, Coenen HH, Crouzel C, et al. Amino acids for the measurement of protein synthesis in vivo by PET. Int J Rad Appl Instrum B. 1992;19:227-237.

36. Crawford KW, Bowen WD. Sigma-2 receptor agonists activate a novel apoptotic pathway and potentiate antineoplastic drugs in breast tumor cell lines. Cancer Res. 2002;62:313-322.

37. Azzariti A, Colabufo NA, Berardi F, et al. Cyclohexylpiperazine derivative PB28, a sigma 2 agonist and sigma ${ }_{1}$ antagonist receptor, inhibits cell growth, modulates P-glycoprotein, and synergizes with anthracyclines in breast cancer. Mol Cancer Ther. 2006;5:1807-1816.

38. Choi S-R, Yang B, Plössl K, et al. Development of a Tc-99m labeled sigma-2 receptor-specific ligand as a potential breast tumor imaging agent. Nucl Med Biol. 2001;28:657-666.

39. Barnes JM, Barnes NM, Barber PC, et al. Pharmacological comparison of the sigma recognition site labelled by $\left[{ }^{3} \mathrm{H}\right]$ haloperidol in human and rat cerebellum. Naunyn Schmiedebergs Arch Pharmacol. 1992;345:197-202. 